\title{
Corpuscular Hemoglobin Content
}

National Cancer Institute

\section{Source}

National Cancer Institute. Corpuscular Hemoglobin Content. NCI Thesaurus. Code C139066.

A measurement of the mean red blood cell hemog lobin content within an individual red blood cell, calculated as the product of cell volume and cell hemoglobin concentration. 